\title{
Detecting the Existence of Herding Behavior in Intraday Data: Evidence from the Indonesia Stock Exchange
}

\author{
Setiyono \\ Faculty Economics and Business, Universitas Gadjah Mada, Indonesia \\ Eduardus Tandelilin \\ Faculty Economics and Business, Universitas Gadjah Mada, Indonesia \\ Jogiyanto Hartono \\ Faculty Economics and Business, Universitas Gadjah Mada, Indonesia \\ Mamduh M. Hanafi \\ Faculty Economics and Business, Universitas Gadjah Mada, Indonesia
}

\begin{abstract}
This study attempts to investigate the issue of the existence of institutional herding in the stock market. The existence is detected in the intraday trade data from the Indonesia Stock Exchange (IDX) during up, down, and stable market condition over the period 2003-2005. By using the model of Lakonishok et al. (1992), it is found that the intensity of the existence of institutional herding at the IDX, on average, is 8.4 percent. Institutional investors do not seem to lead their transactions in a certain characteristic of stock. Most of them follow positive-feedback trading strategy while others follow negative-feedback trading strategy. This study also found that the existence of herd behavior at the IDX did not destabilize the market price in a subsequent period.
\end{abstract}

\begin{abstract}
Abstrak: Studi ini mencoba meneliti isu keberadaan perilaku pengikutan investor institusional di pasar saham. Keberadaannya dideteksi dalam data perdagangan intraharian dari Bursa Efek Indonesia (BEI) selama kondisi pasar naik, turun dan pasar stabil pada perioda 2003-2005. Dengan menggunakan model Lakonishok et al. (1992), ditemukan bahwa intensitas keberadaan perilaku pengikutan institusional di BEI rata-rata adalah 8,4 persen. Investor institusional nampaknya tidak mengarahkan perdagangan mereka dalam saham berkarakteristik tertentu. Sebagian besar dari mereka mengikuti strategi perdagangan umpan balik positif, sementara yang lainnya mengikuti strategi perdagangan umpan balik negatif. Studi ini juga menemukan bahwa keberadaan perilaku pengikutan di BEI tidak mengacaukan harga pasar saham pada perioda berikutnya.
\end{abstract}

Keywords: destabilize; herd behavior; stock market price 


\section{Introduction}

Since the beginning of the 1990s herding has already been empirically identified to exist in the stock markets both in developed countries such as U.S, Japan, Australia and in developing countries such as India and Indonesia. Herding is shown to be a pattern of mass behavior that results from the interactions among individuals.

This behavior was formerly assumed to occur only when the market was in a condition of information asymmetry and highly volatility (Alchian 1950), as would happened when an economy was in crisis and when a market was fluctuating extremely. Nevertheless, such behavior is also found when the market is in a stable condition. Hwang and Salmon (2004) surprisingly found that the occurrence of this behavior is more frequent during a stable market than during a market under pressure. As said by Hwang and Salmon (2004), a market cannot be free from the herding behavior, and the issue surrounding this behavior concerns its changing intensity from time to time. So it is reasonable to detect the existence of herding behavior in whatever market condition.

The existence of herding behavior of both domestic and foreign investors at the Indonesia Stock Exchange, IDX (ex-JSX) has been detected using daily data by Neal et al. (2002) and Bowe and Domuta (2004) during the period of Asian crisis in 1997. The studies also found that both domestic and foreign investors engaged in herding behavior, and the existence did not destabilize the market prices of the stocks during the subsequent period. This research is intended to detect the existence of the herding behavior at the IDX with a number of differences especially concerning the period, subject, and type of the data used.
This research focuses on the institutional investors' behavior. The subject is chosen due to the fact that this type of investor has been proven to have order in the strategy of trading i.e. trading by following the herd (Sias 2001). The existence of the herding behavior of the institutional investors, in this research, is detected during a long period of time either when the market condition was rising, falling, or steady. That long period of time enables an observation to be made of the changes of intensity of the herding from time to time.

This research also observes whether the herding is directed at securities with similar characteristics and whether the institutional investors follow trends or follow both positive and negative feedback-trading strategies. This kind of investor is often suspected as being informed-traders who tend to follow the trend and follow themselves, besides herding with each other, inside and outside of the securities with similar characteristics (Sias 2001; and Chakravarty 2001). Furthermore, this research also observes what the tendency of the stocks' market prices is during the period after the stocks are traded with the herding.

During the period 2003-2005 at the IDX, based on the model of Lakonishok et al. (1992), it was found that the intensity of institutional herding was 8.4 percent on average. The intensity of the herding initiated by the sellers was stronger than that initiated by the buyers. Those institutional traders were not obviously directed at the stocks with certain characteristics (risks, company size, and past performance). Some institutional investors followed the positive-feedback trading strategy and some others followed the negative-feedback trading strategy. The intensity of the herding varied in accordance with the passing time, and consistently in line with the findings of Hwang and Salmon (2004), 
which say that the stronger intensity tends to occur when the market is more stable. Abnormal returns within the subsequent period was found to be non-monotonic; therefore, it cannot necessarily be said that it was evidence of price reversal as the consequence of the institutional investors choosing the herding strategy in their stock trading.

The remainder of this is organized as follows. Part B explains the literature review and hypothesis on institutional herding, and the effects of herding on subsequential prices. Part $C$ presents the research method containing the reports on data and samples, herding measurement, and means difference test. The empirical testing along with its results is presented in Part D. Part E contains the conclusion.

\section{Literature Review and Hypotheses}

\section{Herding Models}

From a rational viewpoint, the existence of herding behavior in a stock market can be explained through one or more of three mechanisms: informational externality, payoff externality, and reputation or compensation (Devenov and Welch 1996). Those three mechanisms, which become the reasons why an individual behaves in that way in decision making, can be separately explained by using three models of rational herding: (i) informational based herding, (ii) informational acquisition herding and (iii) reputation and compensation based herding.

\section{Informational Based Herding}

When decision-making is complemented by a volatile condition and imperfect information, an information transmission be- tween individuals is needed to increase the knowledge about the environment condition that affects a decision making. Herding behavior is often chosen to obtain the effect of informational externality. Considering that herding behavior can be carried out by observing the interacting individuals, an information transmission is then assumed to have already occurred. Furthermore, as this herding model sees that inter-individual learning in information searching as being important, therefore, the informational based herding model is also called a social learning model.

Banerjee (1992) calls this social learning model herd behavior and Bikhchandani et al. (1992) call it informational cascades. This model is constructed based on the assumption that an individual only receives private signals and action signals of the predecessors, but cannot learn private signals and the past payoffs of the predecessors. According to this model, herding behavior occurs when an individual can observe in sequential trading the predecessor's actions, and then he makes a decision or acts by imitating the predecessor's actions without considering the private information he has.

In the beginning, a social learning model ignores the importance of verbal communication. This model only admits that information obtained by observing someone else's actions is more credible; in other words, actions speak louder than words. Consequently, this results in an inefficient decision. The opinion on this old herding model then changes because the behavior involving observing the actions of other interacting individuals, basically, involves a process of direct communication and discussion among individuals. Automatically, an extensive information transmission may occur and the amount of information owned by a group increases. 
In other words, a verbal communication becomes very important in the process of information transmission. The social learning model taking verbal communication as something very important is also called a social learning model through a conversation or word-of-mouth learning model.

With an assumption that there are communications and discussions in a decisionmaking process, an individual is considered able to observe not only actions but also the past payoff (Ellison and Fudenberg 1993, 1995; and Banerjee and Fudenberg 2004) and the predecessor's private signals (Bikhchandani et al. 1998). Based on this assumption, the decision made with herding is efficient. Moreover, a more accurate decision will be achieved if the payoff resulting from a certain action can observed in the next period (Cao and Hirshleifer 2000).

\section{Informational Acquisition Herding}

Herding behavior can also probably be explained by the existence of the payoff externality effect, which is a payoff increase as the result of the increasing number of other investors conducting the same actions. The effects can be shown when all of the informed investors receive information at the same time and decide to direct either the selling or buying to similar assets. The philosophical basis of this behavior model is that an informed investor will become better-off only when trading by following information sources used by other informed investors but by ignoring fundamental information he has already had.

This herding model emphasizing the payoff externality effects is proposed by Froot et al. (1992) and Hirshleifer et al. (1994) and is named informational acquisition herding. This model counts the differences when information is attained by informed investors.
The market, whose investors receive information at different times, has a fundamentally different balance compared to the market whose investors receive simultaneous information. In that kind of market, the more aggressive informed investors will enjoy a larger profit than the late informed investors will. In order to also get profit, the late informed investors apply a strategy of following the behavior of the earlier informed investors. In simple words, this model states that informed investors can follow each other when trading in a stock market.

\section{Reputation and Compensation Based Herding}

A personal stake in herding behavior comes up when there is no perfect information in the market. In such a condition, an investor may or may not follow another investor's action due to a vested interest, for example to keep or achieve reputation, career, or certain compensation. Herding behavior driven by a personal stake on reputation has been identified by Scharfstein and Stein (1990), Zwiebel (1995) and Prendergast and Stole (1996). This model is based on a notion that in a certain situation a manager will follow other managers' investment decisions by ignoring his private information when putting his reputation or career on stake.

Unlike the arguments of reputation based herding theory, Brennan (1993) emphasizes the importance of compensation in the contract making between the agent and the principal as the basis for developing the theory of herding. The idea that a principal may deal with an agent's uncertainty of ability in making a right decision becomes the basis for developing this herding model. Empirical evidence supports the theory is shown by Maug and Naik (1995), stating that the performance rules, such as incentive for good 
performing agents (to reduce any agency conflicts), explicitly set by the principal can bring about herding behavior in the agents. The informed agents may ignore their private information and follow the other probably uninformed agents in order to comply with the rules set by the principals.

\section{Institutional Investors}

Generally, institutional investors are the informed traders who prefer to engage in herding in their stock trading. It means that these people follow each other in trading the same stocks. Moreover, they also follow the trend or themselves in trading the same stocks (Chakravarty 2001; and Sias 2001). In this research, it is a general hypothesis that institutional investors prefer to engage in herding. The literature review presented in this part aims to give explanation as a theoretical basis in developing specific hypotheses, triggered by the previous general hypothesis.

\section{The Existence of Institutional Herding}

Observing the institutional herding behavior is not generally conducted when the market is in a state of high uncertainty, even though Patterson and Sharma (2004) keep choosing this condition. These behaviors are found in various markets such as in U.S, by Lakonishok et al. (1992), Wermers (1999), and Jones et al. (1999), in Japan by Iihara et al. (2001) and Hanafi (2003), and in India by Batra (2003). In the U.S stock market within different periods the existence of herding with different intensity is found. Lakonishok et al. (1992) find that the intensity reaches 2.7 percent average, while Wermers (1999) and Jones et al. (1999), find each of 3.4 and 1.6 percent.
What has been said by Hwang and Salmon (2004) can possibly be true that a market is not perfectly free from the existence of herding. During a certain period, the intensity can possibly be higher, similar to, or lower than another period. It is assumed that the existence of herding is not in line with the market uncertainty, or its existence is not positively related to the market volatility. It is hypothesized that the institutional investors engage in herding when trading stocks at the IDX, and the intensity can change over time.

\section{The Herding Towards the Security Characteristics}

It is assumed that the institutional investors tend to trade stocks having similar characteristics. Falkenstein (1996) and Gompers and Metrick (2001) have observed the demand of stocks by institutional investors based on various characteristics such as price per share, liquidity, firm size, the number of papers mentioning the names of certain companies, the length of period of the companies listed on the market, return volatility (level of risk), book to market value ratio, and the past performance, etc.

This research focuses on some variables of the stocks' characteristics, i.e. the level of risk, past performance, and firm size. Similar findings have been shown by Falkenstein (1996) and Gompers and Metrick (2001) that institutional investors prefer more risky stocks. Nevertheless, the preference of institutional investors towards smaller stocks and good past performance found by Falkenstein (1996) cannot be found in the research of Gompers and Metrick (2001). According to the study of Gompers and Metrick (2001), institutional investors prefer larger stocks with bad past performance. Despite the con- 
tradiction between these two findings concerning the investors' preference towards the size of the firm and the past performance, the previous researches (see Lakonishok et al. 1992; Wermers 1999; and Sias 2001) support the idea that institutional investors prefer the smaller companies' stocks with good past performance. The stocks with certain characteristics (risk, size, and past performance) that become the preference are supposed to be traded with a higher intensity of herding than those not becoming the preference. It is assumed that the intensity of the existence of herding-buy is higher on the stocks with high-risk, small-size, and good past performance, vice versa.

\section{Trend Following}

The institutional investors often follow the trends in trading at the market. This is found in almost every observed market. They tend to buy the stocks with good past performance and sell those with bad past performance, or follow a positive-feedback trading strategy. In the U.S stock market, this kind of trading can be seen in the studies by for example Lakonishok, et al. (1992), Jones et al. (1999), Nofsinger and Sias (1999) and Sias (2001). In Asian stock markets, this strategy can also be found in Japan (Iihara et al. 2001) and in India (Batra 2003).

Besides following the positive-feedback strategy, institutional investors also prefer to adopt a contrarian strategy, that is buying stocks after the price per share decreases and sell them after the price per share increases. (Bozcuk and Lasfer 2005). Such a trading strategy is also followed by informed traders and presented in the research by Brennan and Cao (1996). These researches explain that the strategy to follow the trend conducted by in- stitutional investors can possibly be either the positive-feedback trading strategy, or negative-feedback trading/contrarian strategy. It is assumed that institutional investors prefer to follow the trend in their trading strategy and prefer to choose a positive-feedback strategy as shown by previous various findings. They buy stocks with good past performance more often than buying stocks with bad past performance.

\section{Institutional Investor Return}

According to Hartono (2008: 511), in a market in which some of the investors have more information and some others do not, there will not be any difference between abnormal return enjoyed by some informed investors and that enjoyed by uninformed investors. The informed investors enjoy more abnormal return because the stocks are purchased below the equilibrium price at a certain time, and sold at the new equilibrium price at the next time.

Institutional investors are thought to have better capability in searching, analyzing, and interpreting the information (Kraus and Stoll 1972a), along with their sophisticated ways (Gompers and Metrick 2001). People also believe that they have much better capability than do individual investors in engaging in diversification. When there is asymmetrical information and some unsophisticated investors, the equilibrium price will be still below the true equilibrium price. The institutional investors who can analyze and interpret the information correctly will respond appropriately by buying the cheap stocks and then selling them when the price shows a new equilibrium. As a result, those institutional investors take the benefit of the abnormal return, while the others do not. 


\section{Reversal or Continuation}

When the institutional investors choose a positive-feedback strategy along with their herding behaviors at a certain level, it is assumed that this has the potential to suppress the market to make the prices unstable. This may happen due to the fact that the behavior causes excess demand for certain stocks i.e. those with good past performance. If the demand is not based on appropriate information, the stock prices are thought to have reversal in the subsequent period.

Testing the hypothesis that institutional trading drives the price reversal shows the result that this hypothesis does not have any support from the data observed. Although there is relatively minor evidence on the existence of herding and positive-feedback trading, Lakonishok et al. (1992) are incapable of providing sufficient data to support the hypothesis. The continuation of the market price in the subsequent period may reflect the informationally efficient market condition.

It is suspected that institutional trading has a valuable information signal. A large instance of trading is thought of as being more informative due to having information signals about the company's prospects, than a small trading which is regarded as having less information as to balance the investor's portfolio (Scholes 1972; and Kraus and Stoll 1972b). The large buying conducted by institutional traders is suspected of increasing the price because the trading contains private information. On the other hand, it is also assumed that a large instance of selling causes negative price reaction due to the fact that the trading carries information showing that the prospects of the company are negative (Bozcuk and Lasfer 2005). If a large trade has information, the market price is supposed to be influenced by excess demand and excess supply at the previous time. The higher the excess demand on a certain kind of stock, the more the stock market will increase in the subsequent period; and the higher the excess supply on a certain kind of stock, the more the stock market will increase in the subsequent period.

\section{Research Method}

\section{Data and Samples}

This research tests some data samples of companies' stock transactions listed on the Indonesia Stock Exchange (IDX) during the period 2003-2005. The raw data needed for this study are the intradaily data. The general criterion for the companies to be included in these research samples is the data availability. The companies must provide data such as intradaily transaction data to cover dates, prices, volume, kinds of trading, and daily closing stock prices. Two other specific criteria to be fulfilled by the companies concern their being active in making transactions and the existence of block trade.

\section{Herding Measurement}

In this paper, measuring the variable of the existence of herding is conducted by applying the procedure developed by Lakonishok et al. (1992) and combined with Wermers (1999). This aims to find out the weekly intensity of institutional (block) ${ }^{1}$

${ }^{1}$ As applied by Kraus, and Stoll (1972b), and Holthausen et al. $(1987,1990)$, the institutional trade is represented by block trade, that is, a trade at least 50.000 shares. 
herding during the period 2003-2005. The first step is estimating the buyer-initiation and seller-initiation by reducing the present price with the previous price (Lee and Ready 1991). The measuring process using a model of Lakonishok et al. (1992) is as follows.

1. Determine the proportion of block investors buying stock (i) in the week ( $\mathrm{t}$ )

$$
\mathrm{p}(\mathrm{i}, \mathrm{t})=\frac{\mathrm{B}(\mathrm{i}, \mathrm{t})}{[\mathrm{B}(\mathrm{i}, \mathrm{t})+\mathrm{S}(\mathrm{i}, \mathrm{t})]}
$$

2. Determine the proportion of block investors buying stocks at IDX in the week ( $t$ )

$$
p(t)=\frac{\sum_{i=1}^{i=N_{i t}} B(i, t)}{\left[\sum_{i=1}^{i=N_{i t}} B(i, t)+\sum_{i=1}^{i=N_{i t}} S(i, t)\right]}
$$

3. Determine the adjustment factor

$$
\mathrm{AF} \quad(\mathrm{i}, \mathrm{t})=\mathrm{E}\{|\mathrm{p}(\mathrm{i}, \mathrm{t})-\mathrm{p}(\mathrm{t})|\}
$$

4. Calculate the herding intensity on stock (i) in the week $(\mathrm{t})$

$$
H(i, t)=|p(i, t)-p(t)|-A F(i, t)
$$

5. Calculate the herding intensity at IDX in the week $(\mathrm{t})$ by averaging $\mathrm{H}(\mathrm{i}, \mathrm{t})$ that calculated across all samples per week.

$A$ number of notations in equation (1) through (4) is defined as follow:

a. $B(i, t)$ is number of block investors buying stock (i) in the week (t);

b. $S(\mathrm{i}, \mathrm{t})$ is number of block investors selling stock (i) in the week (t); c. $p(\mathrm{t})$ is the expected proportion of block investors buying in that week relative to the number of active block investors, it is aggregated from entirely stock;

d. $A F(\mathrm{i}, \mathrm{t})$ is adjustment factor determined by considering the fact that under null hypothesis of no herding;

e. Nit is number of stocks traded at least one block investor in the week $(\mathrm{t})$;

f. $p(i, t)$ is the proportion of block investors buying stock (i) in the week (t);

g. $|\mathrm{p}(\mathrm{i}, \mathrm{t})-\mathrm{p}(\mathrm{t})|$ is excess buying or excess selling of stock (i) from the average of block buying or block selling in the week (t).

After the intensity of herding is measured, stocks in a certain period can be divided into three groups, i.e. stocks bought with herding, stocks sold with herding, and stocks not traded with herding. The stocks not traded with herding are those having negative $\mathrm{H}(\mathrm{i}, \mathrm{t})$ and stocks without herding. To determine whether herding is initiated by buyers $(\mathrm{BH})$ or initiated by sellers $(\mathrm{SH})$, the criteria constructed by Wermers (1999) are applied, with the herding rule:

$$
\begin{aligned}
& \mathrm{BH}(\mathrm{i}, \mathrm{t})=\mathrm{H}(\mathrm{i}, \mathrm{t}) \mid \mathrm{p}(\mathrm{it})>\mathrm{p}(\mathrm{t}) \text {, and } \\
& \mathrm{SH}(\mathrm{it})=\mathrm{H}(\mathrm{i}, \mathrm{t}) \mid \mathrm{p}(\mathrm{it})<\mathrm{p}(\mathrm{t})
\end{aligned}
$$

\section{Mean Difference Test}

Some hypotheses constructed in this paper need the mean difference test technique to test them. The test comparing the average of 2 samples will be applied by using an independent sample test method (t-test), the average of the pair will be tested by using a pair samples test method, and the average of more than 2 samples will be tested by using the ANOVA method. 


\section{Result}

\section{Market Condition}

The market condition during 20032005 , as reflected by the fluctuation of market index returns, can be seen in Figure 1. The market return fluctuated with the highest average rise reaching 13.90 percent in January 2004, and the lowest average rise reaching 1.35 percent in February 2004. Meanwhile, the highest average fall reached 8.30 percent in May 2004, and the lowest average fall was 0.38 percent in August 2003.

Figure 1 shows the market fluctuating condition. This market volatility is shown by the market index returns either above or below the original value. During the research, this market index volatility was signaling a volatility of the market condition and is statistically shown through the value of the standard deviation of 0.02655 of 0.00683 as the average value. The highest return of the market index is 0.08391 , which occurs in the fourth week of December 2003, and the lowest is 0.08764 , which occurs in the fourth week of April 2004. Of the 153 observed weeks, there are 16 dates showing an extreme market fluctuation. A market is said to be 'rising' only when, within those dates, it has market returns that stay in the highest $8(5 \%$ of the weekly return data distribution), and is said to be 'falling' when the market returns stay in the lowest 8 .

Some statistical values resulting from the description of the market return data indicate that the condition of the market covers quiet market (the market return is minimum close to zero), up-market (the market return is positive), and down-market (the market return is negative). Therefore, the stock market condition at the IDX is a perfect setting for

Figure 1. Market Return Period of Years 2003-2005

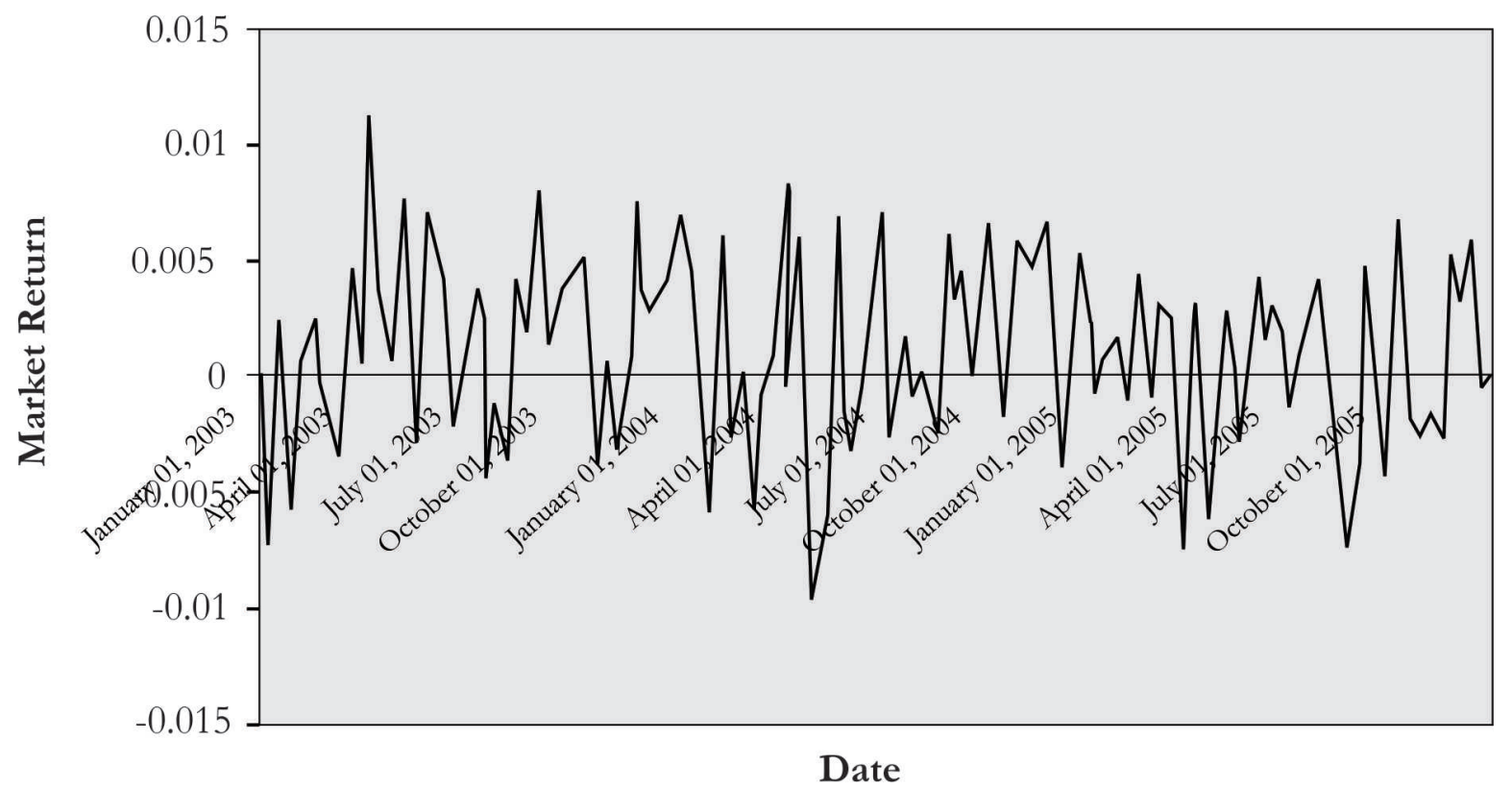


detecting the herding behavior in price decision making as required by this study.

\section{Institutional Herding Existence}

By using the model of Lakonishok et al. (1992), the detection of herding towards 1.875 stocks found that there were 756 stocks traded by way of herding. Table 1 shows the average intensity of institutional herding reaches 8.4 percent. The intensity of herding initiated by institutional buyers upon 353 stocks has an average of 7.7 percent. This is lower than the intensity of herding initiated by institutional sellers, which reaches an average of 9.1 percent, occurring on 403 stocks.

Using quarterly data in U.S, this stronger herding initiated by sellers is also detected by Wermers (1999). The existence of herding found in the IDX daily data is also detected by Neal et al. (2002) and Bowe and Domuta
(2004), in which herding is conducted by both domestic and foreign investors. The existence of herding found in this research signals that the behavior of institutional investors at the IDX resemble informed agents. They follow each other in stocks trading.

The results of detecting herding at the IDX during the period of the research show that herding behavior takes place not only when the market has an extreme fluctuating condition, but also when the market is stable. The results of the means difference test show that the intensity of herding in a market during an extreme fluctuating condition is lower than that during the time in which the market does not experience extreme changes (Table 2 Panel A). In an extremely changing condition, the average intensity of herding is as much as 0.066 , and it is lower than 0.087 when the market is not experiencing an extreme change.

\section{Table 1. Existence of Institutional Herding}

Existence of institutional herding is detected from intraday transaction data at IDX period of years 2003-2005. The existence of herding can be expressed as the intensity value estimated by using a Lakonishok et al. (1992) model. The average intensity of herding existence is reported, both for all samples and each trade side: buy-side and sellside. Standard errors are reported along with their means in parentheses. Whether the existence is initiated by buyer (BH) or seller (SH) determined by using a Wermers (1999) rule:

\begin{tabular}{cccc}
\hline Variable & $\begin{array}{c}\text { Herding } \\
\text { Intensity }\end{array}$ & $\begin{array}{c}\text { Buyer Initiated } \\
\text { Herding Intensity }\end{array}$ & $\begin{array}{c}\text { Seller Initiated } \\
\text { Herding Intensity }\end{array}$ \\
\hline Mean (std. deviation) & $0.084(0.083)$ & $0.077(0.079)$ & $0.091(0.086)$ \\
Observation (n) & 756 & 353 & 403 \\
\hline
\end{tabular}

Estimation result of the intensity of herding existence for each stock is not shown in this paper. 


\section{Table 2. Mean difference test results}

Panel A presents the result of mean difference tests for the intensity of herding between two subsets of market conditions: extremely volatile and stable. Panel B presents the result of mean difference tests for the intensity of herding according to period of time changes: 2003, 2004 and 2005. Standard errors are reported along with their means in parentheses. Existence of herding is expressed as the institutional herding intensity estimated by using a Lakonishok et al. (1992) model.

\begin{tabular}{llll}
\hline \multicolumn{1}{c}{ Test } & \multicolumn{1}{c}{ Condition - Category } & Mean (S.E) \\
\hline \multicolumn{4}{c}{ Panel A. Mean difference test } \\
\hline Market condition & Extremely volatile & 105 & $0.066(0.0066)$ \\
& Stable & 651 & $0.087(0.0033)$ \\
& Levene's statistic & & $9.019^{* * *}$ \\
& t-test & & $2.508^{* * *}$ \\
\hline \multicolumn{1}{c}{ Panel B. ANOVA } & & \\
\hline Year & 2003 & 46 & $0.040(0.0018)$ \\
& 2004 & 44 & $0.037(0.0017)$ \\
& 2005 & 35 & $0.029(0.0016)$ \\
& Levene's statistic & & 1.631 \\
& t-test & & $7.112^{* * *}$ \\
\hline
\end{tabular}

*** Significant at the 1 percent level.

These findings seem to be evidence supporting the statement of Hwang and Salmon (2004) that there will be no market perfectly free from the existence of herding, and the intensity of its existence varies from time to time. Table 2 Panel B presents the result of ANOVA. At the level of significance of 1 percent, there is a variety of herding intensity during the period of this research. The intensity of herding decreases annually with the highest intensity as high as 0.0388 occurring in 2003, and the lowest intensity was 0.0293 in 2005.

\section{Characteristic Based Herding}

Table 3 shows the results of the mean difference tests for the herding intensity according to stock characteristics: firm size, risk, and past performance of stocks. During the research, the institutional investors at the IDX do not seem to have a monotonous preference with regard to the firm size. The results of the mean difference test that have not been uploaded in this paper show that the herding intensity of buying blocks is higher on small and large stocks, and the herding in- 
tensity of buying blocks is lower on medium stocks. There is a similar tendency on the selling side, though it is not statistically significant. These findings seems to justify the previous findings both that the institutional prefers small stocks (Falkenstein 1996), and vice versa (Gompers and Metrick 2001). Institutional investors might not have monotonous preference for either large or small stocks.
Meanwhile, seen from the characteristics of the risk level, their trading prefers the low risk stocks. This finding is different from the previous findings stating that institutional investors prefer stocks with high variation of return (Falkenstein 1996; and Gompers and Metrick 2001). This institutional behavior is rational in order to avoid a relatively big loss if the high-risk stocks are chosen.

\section{Table 3. Mean difference test results}

This table presents the result of mean difference tests for the intensity of herding according to stock characteristics: firm size, risk, and past performance of stock. Standard errors are reported along with their means in parentheses. Existence of herding is expressed as the institutional herding intensity estimated by using a Lakonishok et al. (1992) model. Whether the existence is initiated by buyer $(\mathrm{BH})$ or seller $(\mathrm{SH})$ determined by using a Wermers (1999) rule:

$$
\mathrm{BH}(\mathrm{i}, \mathrm{t})=\mathrm{H}(\mathrm{it}) \mid \mathrm{p}(\mathrm{i}, \mathrm{t})>\mathrm{p}(\mathrm{t}) \text {, and } \mathrm{SH}(\mathrm{i}, \mathrm{t})=\mathrm{H}(\mathrm{i}, \mathrm{t})<\mathrm{p}(\mathrm{t})
$$

Firm size is measured by a market capitalization value. Risk is measured by a beta coefficient that estimated by using a market model. Past performance is measured by a value of previous abnormal return.

\begin{tabular}{lcrr}
\hline \multicolumn{1}{c}{ Category } & Firm Size & \multicolumn{1}{c}{ Risk } & Past Performance \\
\hline \multicolumn{4}{c}{ Buyer Initiated Herding } \\
\hline Low & $0.088(0.008)$ & $0.098(0.010)$ & $0.079(0.007)$ \\
Medium & $0.069(0.007)$ & $0.082(0.007)$ & $0.076(0.007)$ \\
High & $0.094(0.010)$ & $0.072(0.007)$ & $0.074(0.007)$ \\
Levene Statistic & $2.41^{*}$ & $5.23^{* * *}$ & 0.72 \\
t-test & $2.77^{*}$ & $2.23^{*}$ & 0.17 \\
Observation (n) & 344 & 344 & 337 \\
\hline & Seller Initiated Herding & $0.094(0.008)$ \\
\hline Low & $0.088(0.007)$ & $0.100(0.010)$ & $0.094(0.008)$ \\
Medium & $0.084(0.007)$ & $0.086(0.007)$ & $0.072(0.006)$ \\
High & $0.086(0.008)$ & $0.075(0.006)$ & $4.24 * *$ \\
Levene Statistic & 0.047 & $4.91^{* * *}$ & $3.02^{* *}$ \\
t-test & 0.115 & $2.73^{*}$ & 399 \\
Observation (n) & 396 & 397 & \\
\hline
\end{tabular}

*** Significant at the 1 percent level, ** Significant at the 5 percent level, and * Significant at the 10 percent level. 


\section{Trend Following}

The test results not uploaded in this paper show an early indication that institutional investors follow trends. This is clearly seen from the results of the analysis on the intensity of herding-buy and sell based on the characteristics of the stocks' past performance. When viewed from the intensity of herding-sell, they look like positive-feedback traders, but when viewed from the intensity of herding-buy, they also like negativefeedback trading. Though statistically it is not significant, this finding is also consistent with what is obtained from the means difference test of excess-demand represented by $D$-ratio and $N$-ratio. Most institutional investors choose the positive-feedback strategy as shown by the highest $N$-ratio on the stocks with good past performances, and others choose the negative-feedback strategy as shown by $\mathrm{D}$-ratio which is positive to the stocks with bad past performances (Table 4).

The means difference $D$-ratio and $\mathrm{N}$-ratio tests give different results. It is perhaps caused by two things: a different number of followers of a certain strategy and a different trading volume. Although most institutional investors at the IDX prefer to choose a positive-feedback trading strategy, some institutional investors use a negativefeedback strategy with a larger amount of buying. Since the negative-feedback institution makes a large trading, while the positivefeedback institution does not do the same, there is then an excess-demand towards the stocks with bad past performances. The negative-feedback or contradictory trading strategy used by institutional investors during this research is also done by informed institutional investors as detected by Brennan and Cao (1996) and Bozcuk and Lasfer (2005).

\section{Table 4. Test for trend following strategies}

Tests are employed by analyzing excess-demand for each stock. Mean difference of the excess-demands are tested according to past performance categories. Standard errors are reported along with their means in parentheses. Firm performance is measured by the abnormal return, estimated as: $E_{t}=R_{i t}-E\left(R_{i t}\right)$. The excess-demand can be expressed as D-ratio and N-ratio. D-ratio for a given stock-week, i, can be defined as:

$$
D-\operatorname{ratio}(i)=\frac{[\operatorname{IDR} \text { buys }(i)-\operatorname{IDR} \text { sells }(i)]}{[\operatorname{IDR} \text { buys }(i)+\operatorname{IDR} \text { sells }(i)]}
$$

N-ratio for a given stock-week, i, can be defined as:

$$
\mathrm{N}-\operatorname{ratio}(\mathrm{i})=\# \text { buys }(\mathrm{i}) / \# \text { active }(\mathrm{i})
$$

\begin{tabular}{lcc}
\hline Past Performance & D-ratio & N-ratio \\
\hline 1 (worse) & $0.0229(0.021)$ & $0.4665(0.014)$ \\
2 & $-0.0081(0.021)$ & $0.4899(0.015)$ \\
3 (best) & $-0.0004(0.021)$ & $0.5061(0.014)$ \\
\hline
\end{tabular}




\section{Returns for Institutional Investors}

Institutional trading is assumed to have information about the future prospect of the company. Excess-demand (supply) by institutional traders is suspected of influencing the prices in the subsequent period. Analyzing the abnormal return that occurs is conducted to test this assumption.

In the test, there is a convincing difference between the abnormal return received by institutional investors and that received by non-institutional investors. It indicates that there is information asymmetry at the IDX during the period that the research was conducted. In line with the opinion of Kraus and Stoll (1972a), more information at the IDX is absorbed by institutional investors than is obtained by non-institutional investors. As a result, institutional investors (block) get more abnormal return than do the non-institutional investors (non-block) (see Table 5). This abnormal return gap justifies the institutional investors as the informed traders. Therefore, the fluctuation of prices at the IDX during the research might be caused by private information rather than public information.

Besides the distribution aspect of asymmetry information, the return gap can possibly be caused by the investors' capability due to the fact that a good capability is required by investors to analyze as well as intepret the information correctly. If they can analyze and interpret the information correctly, they will respond appropriately. Thus, no single investor predicts whether the stock price is above or below the equilibrium value. In line with the opinions of Gompers and Metrick (2001), it seems that there is a much different quality between two kinds of investors at the IDX, and the institutional investors are much more qualified and capable than are the non-institutional investors. Because of their capability in analyzing, interpreting, and appropriately responding to the informa-

\section{Table 5. Test for mean difference of abnormal returns}

This table reports the mean difference of abnormal returns received by institutional investors from those received by non-institutional investors. Standard errors are reported along with their means in parentheses. The abnormal return can be estimated as: $\mathrm{E}_{\mathrm{t}}=\mathrm{R}_{\mathrm{t}}-\mathrm{E}\left(\mathrm{R}_{\mathrm{t}}\right)$.

\begin{tabular}{|c|c|c|}
\hline \multirow{2}{*}{ Category } & \multicolumn{2}{|c|}{ Mean (standard error) } \\
\hline & All samples & Positive return sample \\
\hline Institutional return & $-0.013(0.003)$ & $0.049(0.003)$ \\
\hline Non institutional return & $-0.015(0.003)$ & $0.047(0.002)$ \\
\hline Difference (d) & $0.001(0.001)$ & $0.002(0.001)$ \\
\hline Correlation (r) & $0.97 * * *$ & $0.95^{* * *}$ \\
\hline t-test & $2.50 * * *$ & $2.78^{* * *}$ \\
\hline Observation (n) & 743 & 288 \\
\hline
\end{tabular}

*** Significant at the 1 percent level. 
tion they have obtained, they can choose and buy the cheap stocks and then sell at the time when the price shows a new equilibrium. Consequently, those smart institutional investors can enjoy the abnormal return better than can the non-institutional investors when a new equilibrium is happening.

\section{Reversal versus Continuation}

The negative abnormal return after a massive selling of stocks is often referred to as selling pressure. By seeing the results of the analysis shown in Table 6, one may see that the average current price decreases after an excess-demand upon stocks and increases after an excess-supply in the past. The excessdemand previously followed by negative return in the subsequent period, changes to become positive when the excess-demand gets higher. It seems that there occurs a reversal from this kind of result due to the negative return in the subsequent period; however, it cannot necessarily be said that the reversal is caused by the noise behavior of liquidity traders at IDX.

It is possible that noise behavior at the IDX has triggered price errors on certain stocks in the past, due to under-reaction towards new information. The stocks having bad performances in the past are considered cheap by these noise traders. The informed traders (institutional investors) receive the same information (correlated) and interpret it appropriately, then perform accordingly (Scharfstein and Stein 1990). Together they buy those cheap stocks, and when there is a quite high excess-demand, the price will be corrected to the proper equilibrium value, close to the fundamental value.

The abnormal return that seems unstable in the subsequent period after the excess-demand can be explained by the frame of information hypothesis (Scholes 1972; and Kraus and Stoll 1972b). The excess-demand towards the cheap stocks in the past by institutional investors can be considered

\section{Table 6. Test for Subsequent Price Across Excess-Demand/Excess-Supply Categories}

Subsequent prices are proxied by abnormal returns. Mean difference of current abnormal returns are tested according to past excess-demand or excess-supply categories. Standard errors are reported along with their means in parentheses. The abnormal return can be estimated as: $E_{t}=R_{t}-E\left(R_{t}\right)$. The excess-demand or excess-supply represented D-ratio, for a given stock-week, i, can be defined as:

$$
\mathrm{D}-\operatorname{ratio}(\mathrm{i})=\frac{[\mathrm{IDR} \text { buys(i) }- \text { IDR sells(i) }]}{[\text { IDR buys(i) }+ \text { IDR sells(i) }]}
$$

\begin{tabular}{lcccc}
\hline \multicolumn{1}{c}{ Category } & Excess-demand & Excess-supply & Excess-demand & Excess-supply \\
\hline \multicolumn{2}{c}{$\mathrm{N}=743$} & \multicolumn{2}{c}{$\mathrm{n}=618$} \\
\hline Total & $-0.0002(0.008)$ & $0.0008(0.005)$ & $0.0011(0.009)$ & $0.0011(0.001)$ \\
Small & $-0.0081(0.003)$ & $0.0030(0.003)$ & $-0.0080(0.003)$ & $0.0009(0.003)$ \\
Medium & $-0.0043(0.002)$ & $0.0003(0.002)$ & $-0.0034(0.002)$ & $0.0019(0.002)$ \\
Large & $0.0160(0.029)$ & $-0.0003(0.003)$ & $0.0193(0.034)$ & $-0.0003(0.003)$ \\
\hline
\end{tabular}

All mean difference of abnormal returns across excess-demand or excess-supply categories are not significant at a common level $(1 \%-10 \%)$. 
as an event containing information signals. The demand curve on the loser stocks in fact tends to increase, but since the excessdemand occurs on the loser stocks, so when the excess-demand is still low, the price is also low (negative abnormal return). When there is a high excess-demand, the prices increase in the herding period. This can be seen through the positive abnormal return due to the high excess-demand by institutional investors in the past.

The same argument applies to the excess-supply towards the winner stocks to explain the abnormal return that seems unstable in the subsequent period. The noise or irrational behavior at the IDX might possibly encourage price error in the past due to overreaction to the new information. The stocks appearing to have good performance in the past are perhaps those regarded expensive by the noise traders. Perhaps the institutional investors have received similar fundamental information and interpreted it accordingly, so that together they sell those expensive stocks to avoid a bigger loss. They share fear together creating a somewhat high excess-supply in the past. Consequently, the stock prices are immediately corrected to the true equilibrium value, close to the fundamental value.

In the information hypothesis frame, the occurrence of excess-supply by institutional investors is believed to have information signals (Scholes 1972; and Kraus and Stoll 1972b). Contradictory traders selling the winners can still enjoy their abnormal return when there are only a few excess-supplies towards those stocks, but when there is a high excess-supply the prices of the winners fall. These falling prices in the subsequent period are marked by negative abnormal return.
By observing the pattern of average abnormal return in the subsequent period, either after the stocks have excess-demand or after the stocks have excess-supply in the past, the results of this analysis, though weak statistically, are consistent with the information hypotheses of institutional trading constructed previously by Scholes (1972) and Kraus and Stoll (1972b). The stock prices that seem to have a reversal in the subsequent period are not sufficient to support the evidence on under-reaction and over-reaction happening in short term.

\section{Conclusions}

With the intradaily transaction data during the period 2003-2005 at the IDX, this research finds that the intensity of institutional herding at the IDX averages 8.4 percent. The intensity of herding appears stronger in a stable market condition. It seems that institutional investors at the IDX like following trends. Most of them adopt a positive-feedback strategy while others adopt a negative-feedback strategy. The behaviors of institutional investors resemble the habits of informed agents.

As traders resembling informed agents, institutional investors also get abnormal returns exceeding the return received by noninstitutional investors. Institutional trading does not explicitly encourage the price reversal because the negative abnormal returns on the stocks experiencing excess-demand are driven by under-reaction conducted by noise traders. This situation will immediately disappear when the demand of institutional investors gets higher. 


\section{Reference}

Alchian, A. A. 1950. Uncertainty, evolution, and economic theory. Journal of Political Economy 58 (3) (June): 211-221.

Banerjee, A. V., and D. Pudenberg. 2004. Word-of-mouth learning. Games and Economic Behavior 46: 1-22.

Banerjee, A. V. 1992. A simple model of herd behavior. Quarterly Journal of Economics 107 (3) (August): 797-817.

Batra, A., 2003. The dynamics of foreign portfolio inflows and equity returns in India. Working Paper (September).

Bikhchandani, S., D. Hirshleifer, and I. Welch. 1992. A theory of fads, fashion, custom, and cultural change as informational cascades. Journal of Political Economy 100 (5): 992-1026.

Bikhchandani, S., D. Hirshleifer, and I. Welch. 1998. Learning from the behavior of others: Conformity, fads, and informational cascades. Journal of Economic perspectives 12 (3): 151-170.

Bonser-Neal, C., S. L. Jones, D. Linnan, and R. Neal. 2002. Herding and feedback trading by foreign investors: The case of Indonesia during the Asian financial crisis. Working Paper (October).

Bowe, M., and D. Domuta. 2004. Investor herding during financial crisis: A clinical study of Jakarta Stock Exchange. Pacific-Basin Finance Journal 12: 387- 418.

Bozcuk, A., and M. A. Lasfer. 2005. The information content of institutional trades on the London Stock Exchange. Journal of Financial and Quantitative Analysis 40 (3) (September): 621-644.

Brennan, M. J. 1993. Agency and asset pricing. Working Paper.

Brennan, M. J., and H. H. Cao. 1996. Information, trade, and derivative securites. Review of Financial Studies 9: $163-208$

Cao, H. H., and D. Hirshleifer. 2000. Conversation, observational learning, and informational cascades. Working Paper.

Chakravarty, S. 2001. Stealth-trading: Which traders' trades move stock prices? Journal of Financial Economics 61: 289-307.

Devenov, A., and I. Welch. 1996. Rational herding in financial economics. European Economic Review 40: $603-615$.

Ellison, G., and D. Pudenberg. 1993. Rules of thumb for social learning. Journal of Political Economy 101 (41): 612-643.

Ellison, G., and D. Pudenberg. 1995. Word-of-mouth communication and social learning. Quarterly Journal of Economics (February): 93-125.

Falkenstein, E. G. 1996. Preferences for stock characteristics as revealed by mutual fund portfolio holdings. Journal of Finance 51 (1) (March): 111-135.

Froot, K. A., D. S. Scharfstein, and J. C. Stein. 1992. Herd on the street: Informational inefficiencies in a market with short-term speculation. Journal of Finance 47 (4) (September): 1461-1484. 
Gompers, P. A., and A. Metrick. 2001. Institutional investors and equity prices. Quarterly Journal of Economics (February): 229-259.

Hartono, J. 2008. Teori Portofolio dan Analisis Investasi ( $5^{\text {th }}$ ed.). Yogyakarta: BPFE.

Hirshleifer, D., A. Subrahmanyam, and S. Titman. 1994. Security analysis and trading patterns when some investors receive information before others. Journal of Finance 49 (5) (December): 1665-1698.

Hwang, S., and M. Salmon. 2004. Market stess and herding. Working Paper (November).

Iihara, Y., H. K. Kato, and T. Tokunga. 2001. Investors' herding on the Tokyo Stock Exchange. International Review of Finance 2 (1/2): 71-98.

Jones, S. L., D. Lee, and E. Weis. 1999. Herding and feedback trading by different types of institutions and the effects on stock prices. Working Paper (August).

Kraus, A., and H. R. Stoll. 1972a. Parallel trading by institutional investors. Journal of Financial and Quantitave Analysis (December): 2107-2138.

Kraus, A., and H. R. Stoll. 1972b. Price impacts of block trading on the New York Stock Exchange. Journal of Finance: 569-588.

Kyle, A. S. 1985. Continuous auctions and insider trading. Econometrica 536 (November): 1315-1335.

Lakonishok, J., A. Shleifer, and R. W. Vishny. 1992. The impact of institutional trading on stock prices. Journal of Financial Economics 32: 23-43.

Lee, C. M. C., and M. J. Ready. 1991. Inferring trade direction from intraday data. Journal of Finance 46 (2) (June): 733-746.

Hanafi, M. M.. 2003. Herding between institutional and individual investors: The Japanese case. Journal of Indonesia Economy \& Business 18 (4): 323-340.

Maug, E., and N. Naik. 1995. Herding and delegated portfolio management: The impact of relative performance evaluation on asset alocation. Working Paper.

Nofsinger, J. R., and R. W. Sias. 1999. Herding and feedback trading by institutional and individual investors. Journal of Finance 54 (6) (December): 2263-2295.

Patterson, D. M., and V. Sharma. 2004. Intra-day trading: Herding versus market efficiency. Working Paper, (August).

Prendergast, C., and L. Stole. 1996. Impetuous youngsters and Jaded old-timers: Acquiring a reputation for learning. Journal of Political Economy 104 (6): 1105-1134.

Scharfstein, D. S., and J. C. Stein. 1990. Herd behavior and investment. American Economic Review 80 (3) (June): 465-479.

Scholes, M. S. 1972. The market for securities: Substitution versus price pressure and the effects of information on share prices. Journal of Business: 179-211.

Sias, R. W., 2001. The behavior of institutional investors: Tests for herding, stealth trading, and momentum trading. Working Paper (March).

Wermers, R. 1999. Mutual fund herding and the impact of stock prices. Journal of Finance 54 (2) (April): 581-622.

Zwiebel, J. 1995. Corporate conservatism and relative compensation. Journal of Political Economy 103 (1): $1-25$. 